\title{
About the Artist: Star Gossage
}

Star Gossage is one of New Zealand's foremost living painters and has Ngati Wai, Ngati Ruanui, French, English, and Portuguese ancestry. She lives in Pakiri, a coastal settlement north of Auckland, and makes paintings that the former Curator Māori from Auckland Art Gallery, Ngahiraka Mason, describes as gentle and powerfully evocative of spiritual connections and tribal narratives. They "affirm her whakapapa, relationships

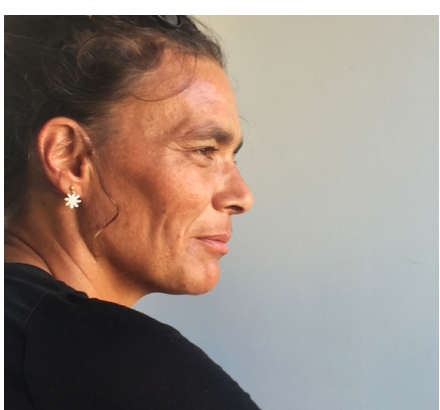

Photo by Moana Nepia to land, sky and ocean" and "experiences shared by her people and the mystical worlds they have inhabited." Works such as Rahui Kiri Rd, for example, acknowledge her chiefly Ngati Wai lineage as great-great-granddaughter of Rahui Kiri, daughter of Ngati Wai chief Te Kiri.

The metaphorical and melancholy nature of such work echoes histories of confiscated lands and displaced communities; creative responses to ideas from writers such as Garcia Lorca; European, Australian, and New Zealand painters; and a personal, very sensual engagement with paint-its physicality, vibrancy, and texture. Star is a self-taught painter with backgrounds in film, theater, and creative writing. During her visit to Honolulu in early 20I6, I talked with her about her work. Sensing herself as part of a creative continuum between the past, present, and future, she said she "feels" her ancestors with her as she works. She collects snapshots and images in her mind of people, places, experiences, and memories and recombines them in her painting.

Star described how some paintings keep "moving . . morphing into each other," others are finished quickly, and some just "do their own thing." At times when she's so tired her eyes "go numb," she still keeps painting. Sometimes she doesn't "see" what she's done or appreciate her works fully until long after they're finished.

MOANA NEPIA

The art featured in this issue can be viewed in full color in the online versions. 


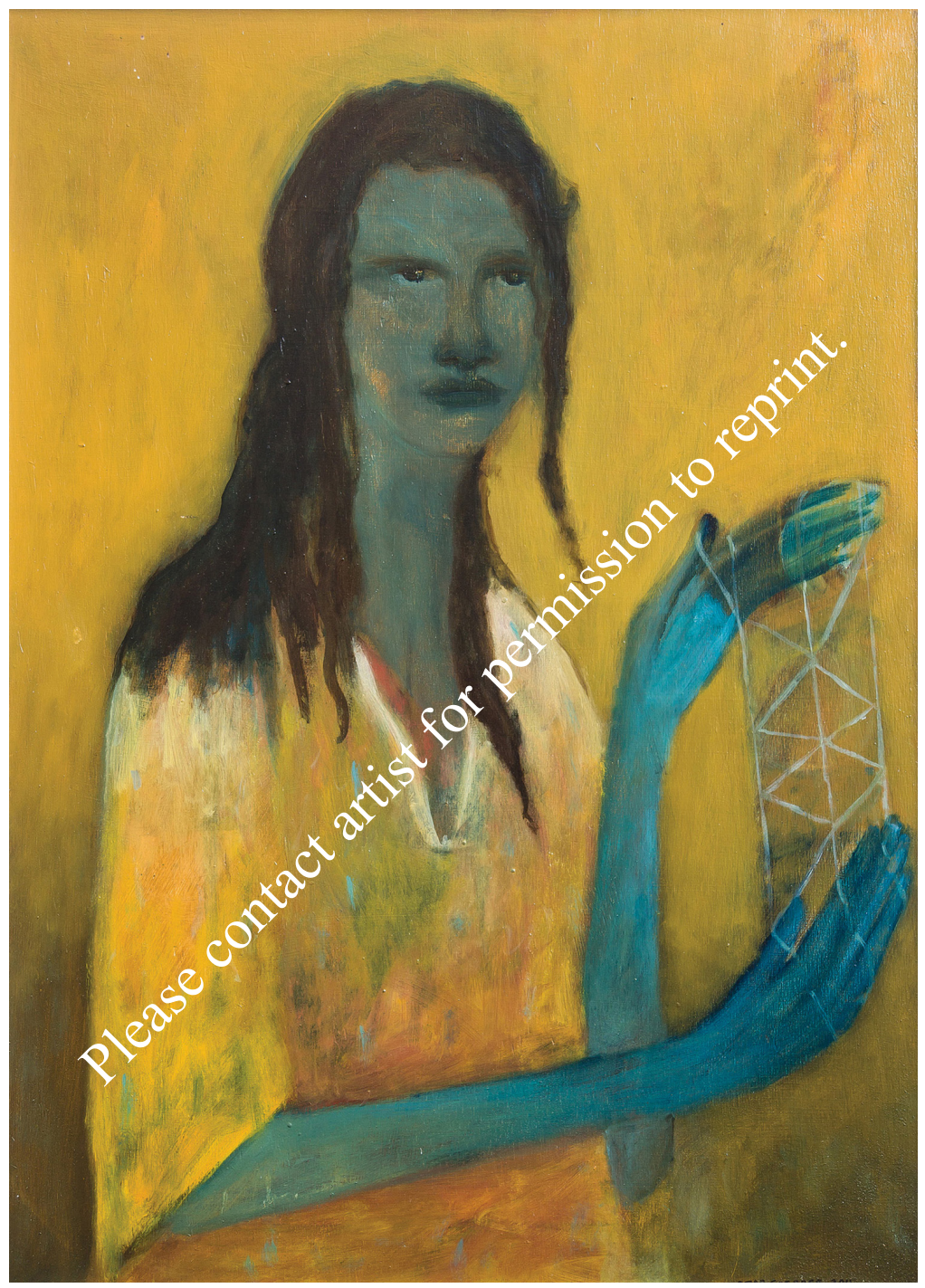

Whai, by Star Gossage, 201 I.

Oil on board, $835 \mathrm{~mm} \times 600 \mathrm{~mm}$. Photo by Kallan MacLeod. Private collection. Reproduced courtesy of the artist and Tim Melville Gallery, Auckland.

Whai (Māori string games) entail learning through observation, rehearsal, coordination, and following others. Translated as "follow," whai may also be termed Te Whai Waewae a Maui, after Maui, whom some iwi (tribal nations) believe was the originator of string games. Children who were quick to learn complex whai were sometimes selected for whare wānanga, the highest schools of learning, where instruction deepened their understanding of relevant cosmologies and genealogies.

MOANA NEPIA 


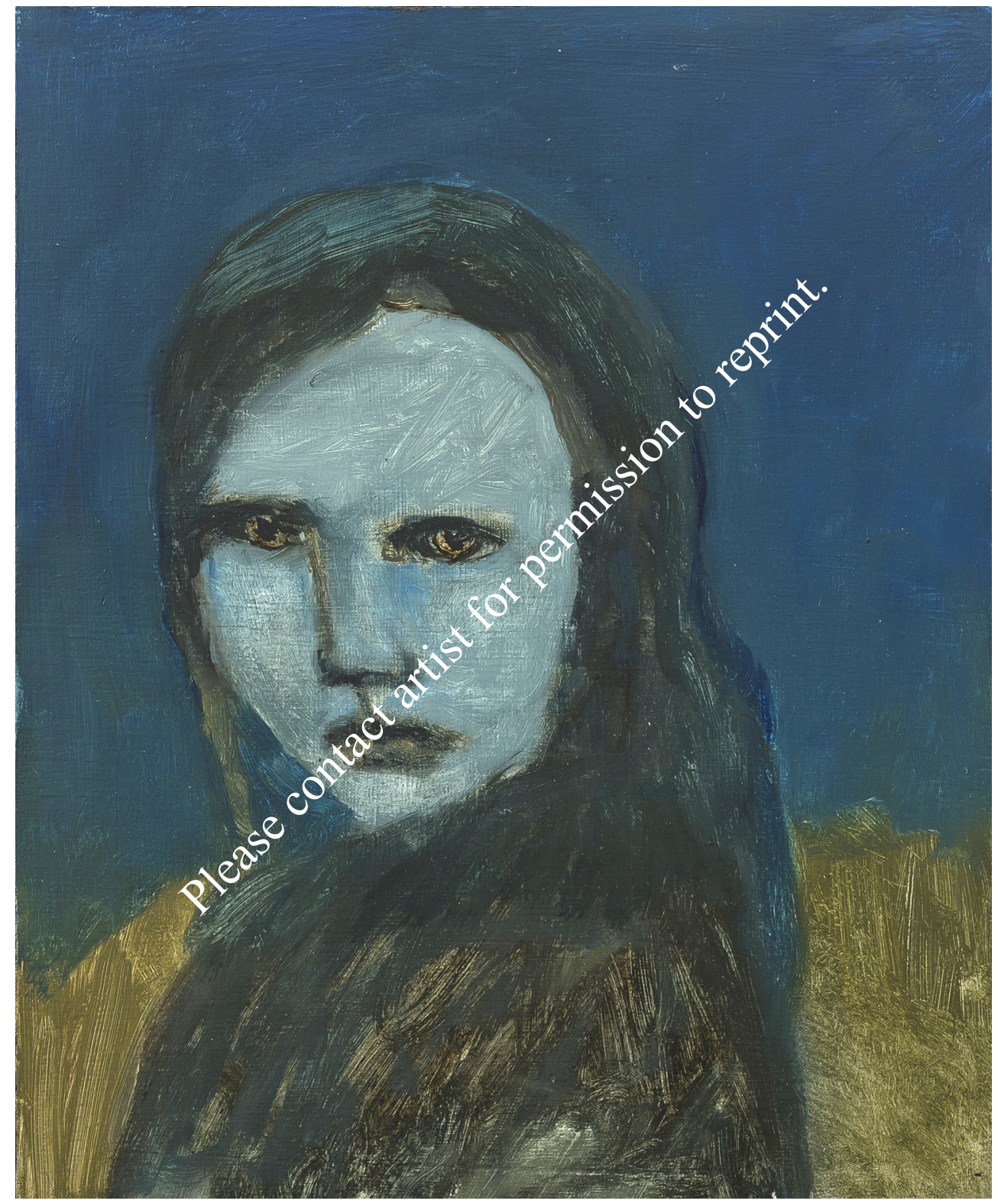

Girl of Evening Blue, by Star Gossage, $20 \mathrm{I} 4$.

Oil on board, $295 \mathrm{~mm} \times 245 \mathrm{~mm}$. Photo by Kallan MacLeod. Private collection. Reproduced courtesy of the artist and Tim Melville Gallery, Auckland.

Me te mea ko Kōpū ka rere $i$ te pae

(Her beauty) like Venus rising above the horizon

WHAKATAUKI (MĀORI PROVERB) 


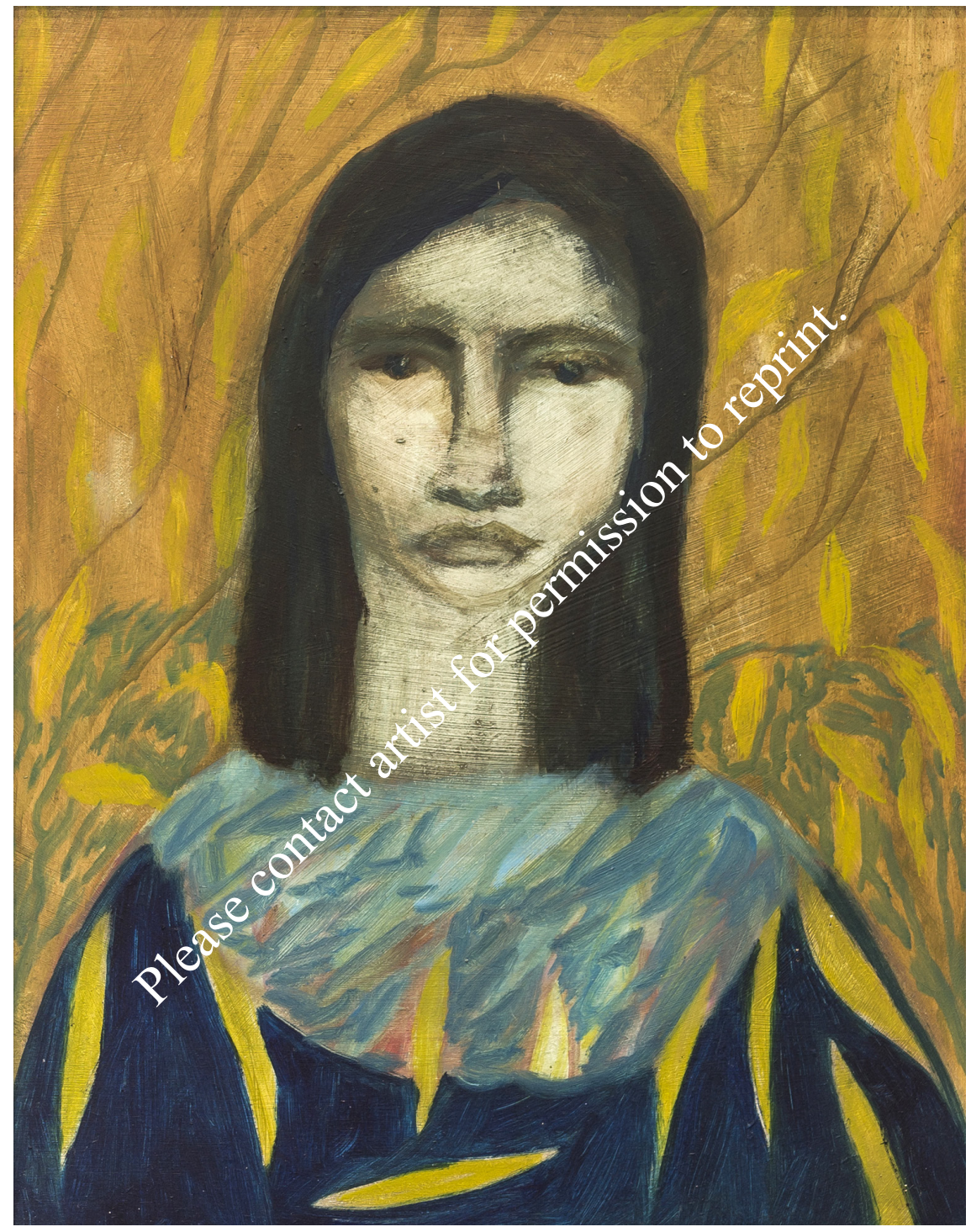

Far Away Eyes, by Star Gossage, 2012.

Oil on board, $445 \mathrm{~mm} \times 345 \mathrm{~mm}$.

Photograph by Kallan MacLeod. Private collection. Reproduced courtesy of the artist and Tim Melville Gallery, Auckland.

Kowhai, entrancing blaze of spring, from naked branches .. . bountiful harvest, yellow garland of hope.

MOANA NEPIA 


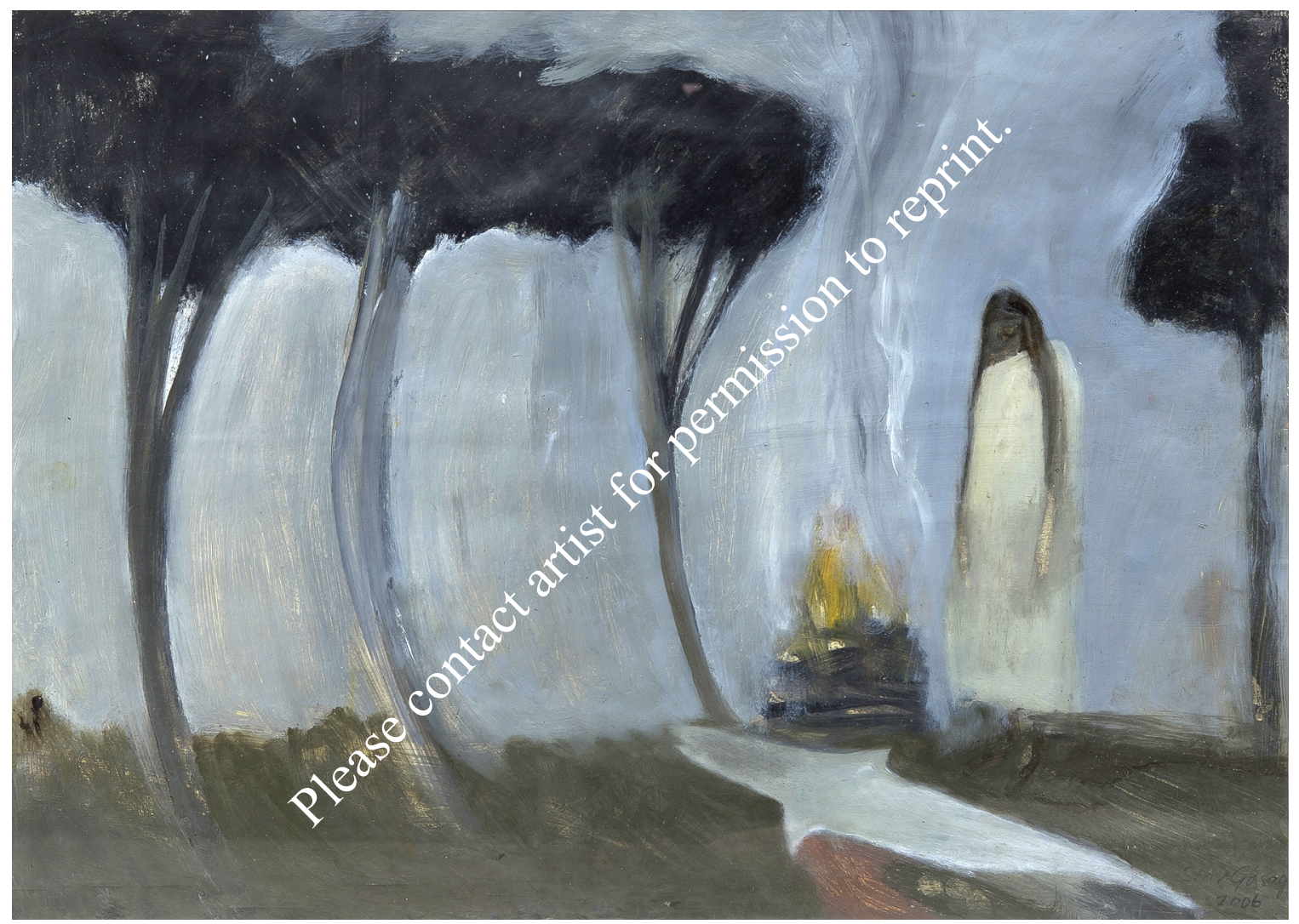

Ahi IV, by Star Gossage, 2006.

Oil on paper, $580 \mathrm{~mm} \times 4$ Iomm. Photograph by Kallan MacLeod.

Private collection. Reproduced courtesy of the artist and Tim Melville Gallery, Auckland.

She who watches over ahi kā ... fire, occupation, enduring presence ... beneath windswept kanuka, sentinel trees, measuring space, marking time...

MOANA NEPIA 


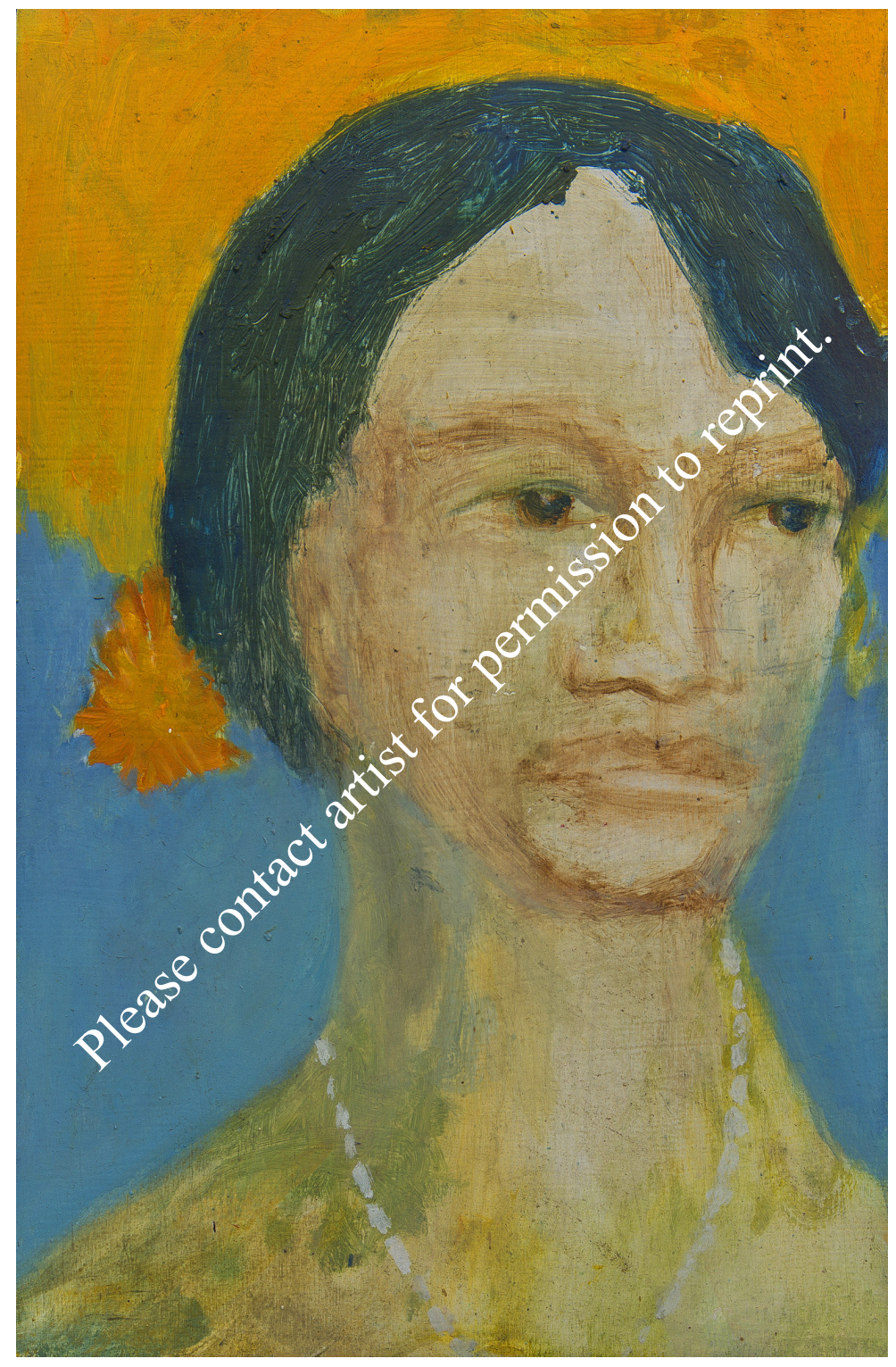

Kane Aloha-young man filled with promise, by Star Gossage, 2016.

Oil on board, 3 I0 $\mathrm{mm} \times 200 \mathrm{~mm}$. Private collection. Photograph by Kallan MacLeod. Private collection. Reproduced courtesy of the artist and Tim Melville Gallery, Auckland.

You are the living face of those gone before... MOANA NEPIA 


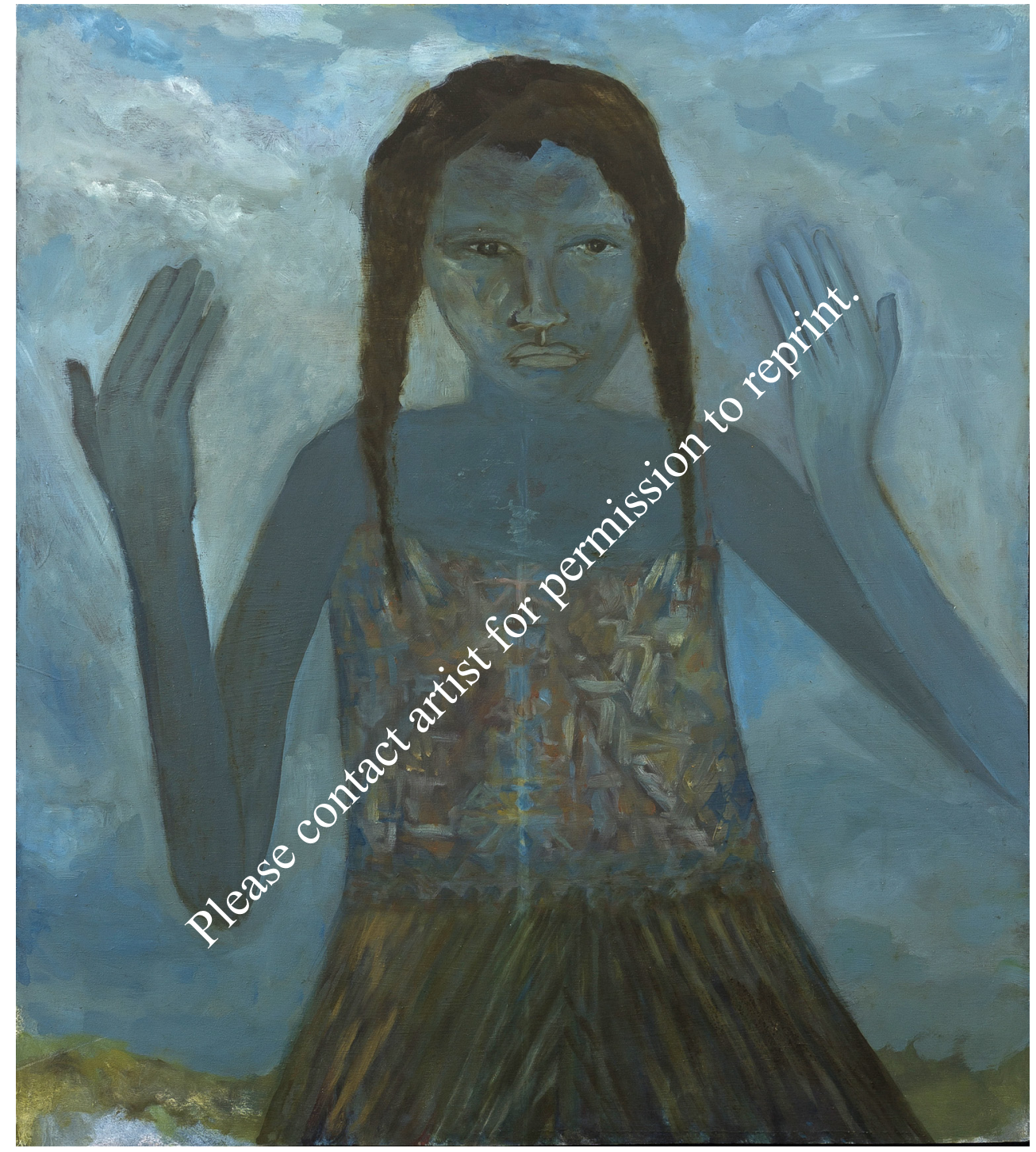

Piki te Ora, by Star Gossage, 2014.

Oil on board, $850 \mathrm{~mm} \times 750 \mathrm{~mm}$. Photograph by Kallan MacLeod.

Private collection. Reproduced courtesy of the artist and

Tim Melville Gallery, Auckland.

A gesture of hands, affirming health, success in life... 


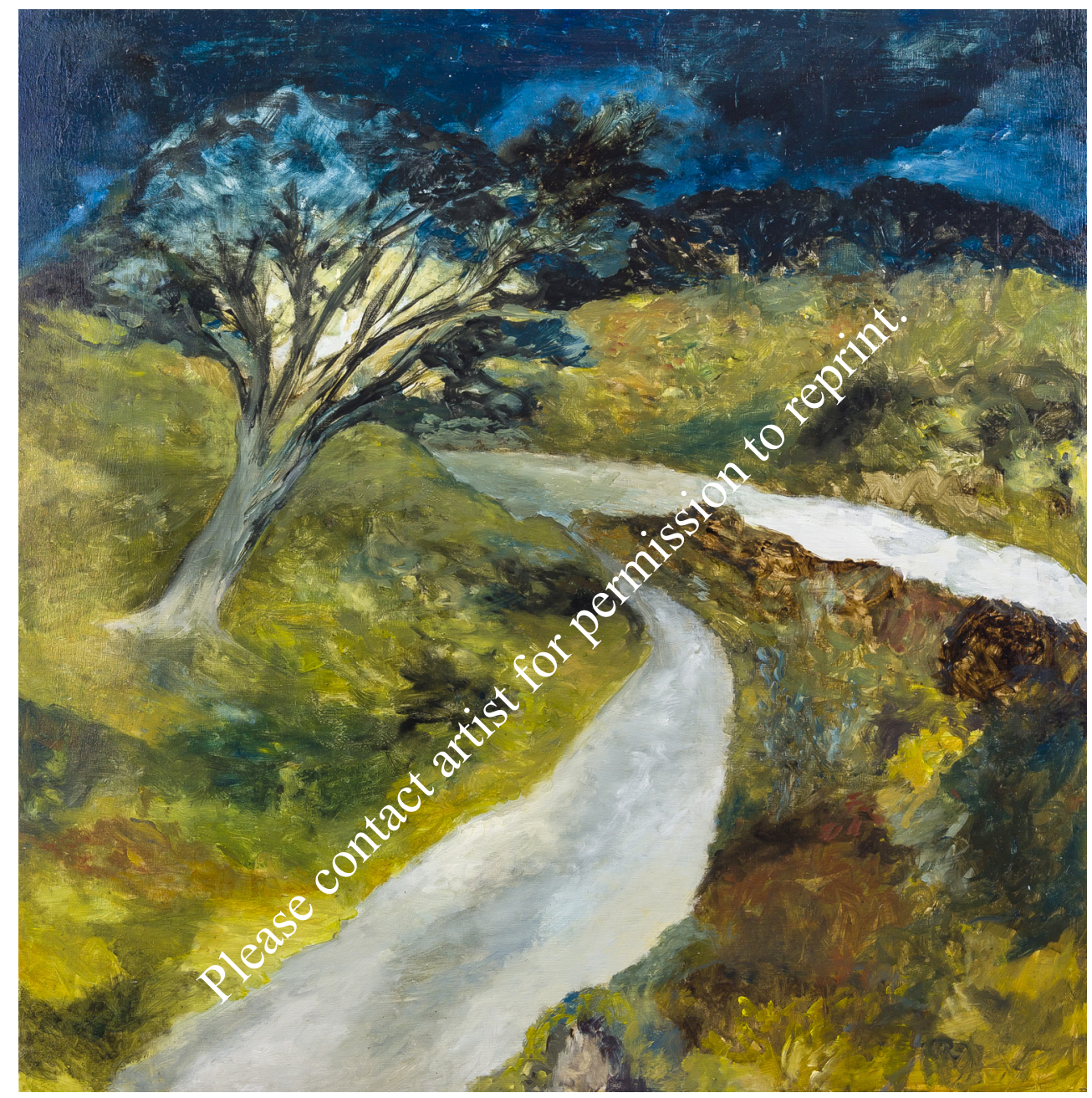

Rahui Kiri Rd, by Star Gossage, 2013.

Oil on board, $800 \mathrm{~mm} \times 800 \mathrm{~mm}$. Photograph by Kallan MacLeod.

Private collection. Reproduced courtesy of the artist and

Tim Melville Gallery, Auckland.

Ancestral pathway for Rahui and her father Te Kiri, Ngati Wai chief...

MOANA NEPIA 


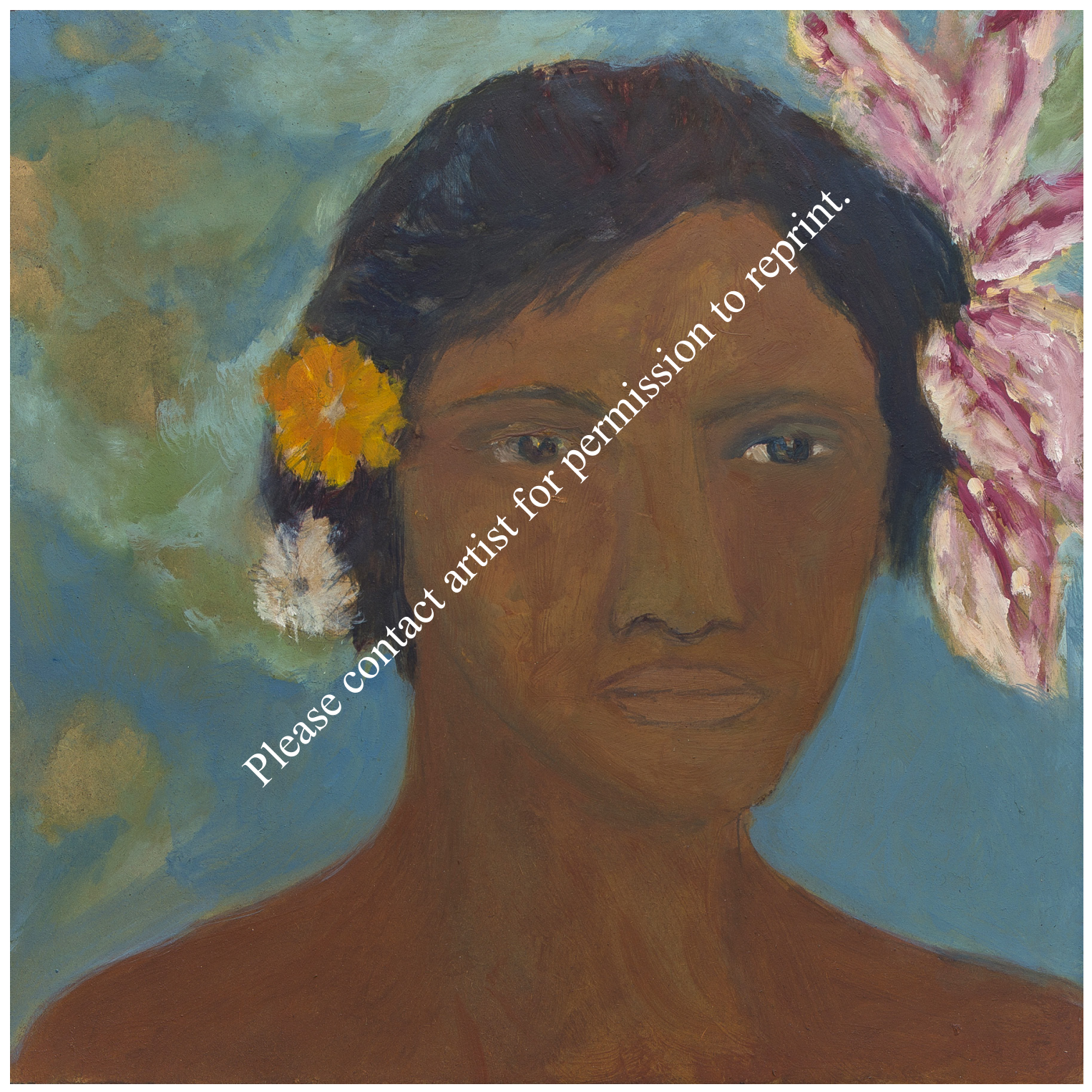

Tolomona, by Star Gossage, 2016.

Oil on board, 3 I 0 mm x 3 I 0 mm. Photograph by Kallan MacLeod. Private collection. Reproduced courtesy of the artist and Tim Melville Gallery, Auckland.

Gauguin gaze . . no whea koe? Where are you from? MOANA NEPIA 


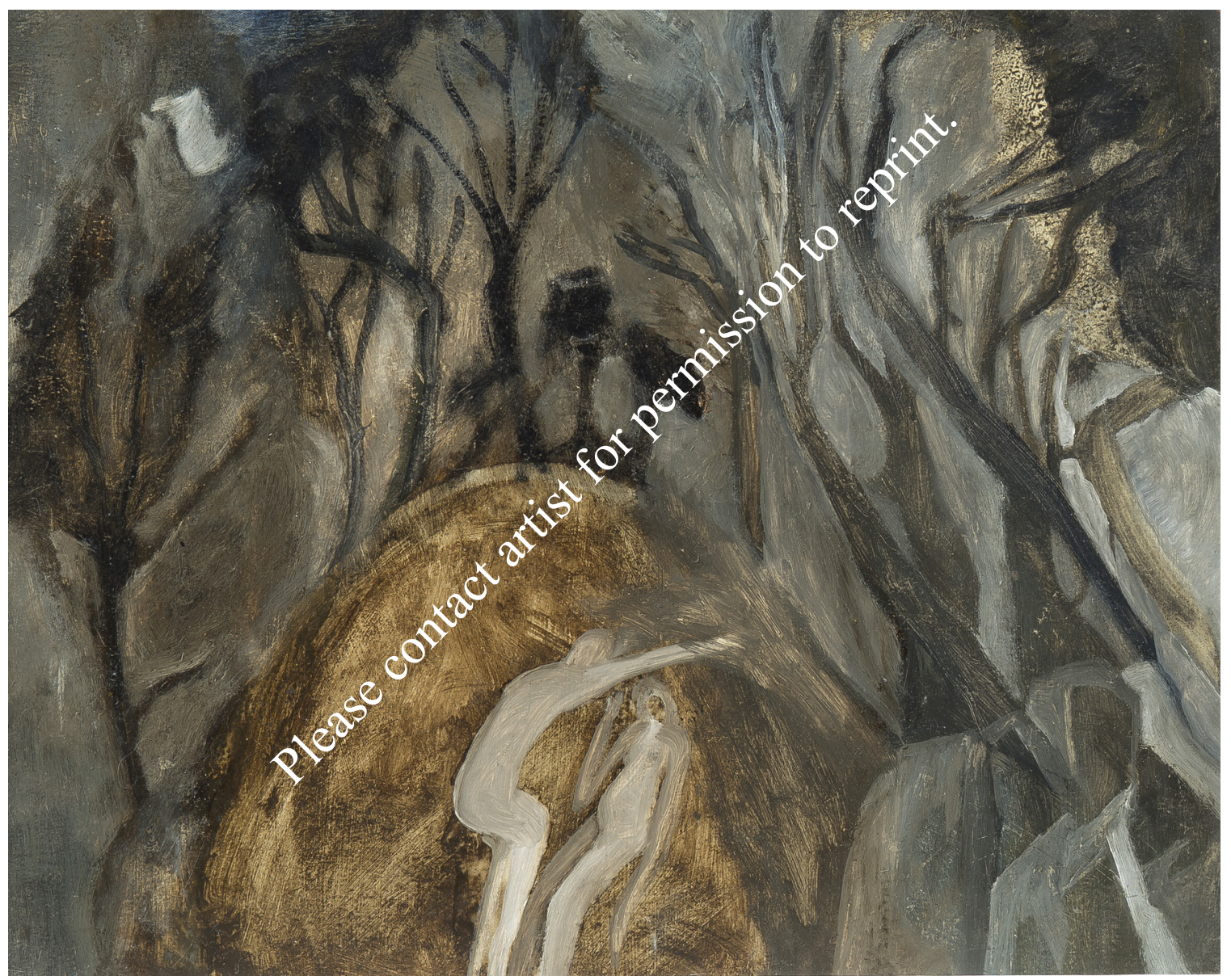

Untitled (Man \& Woman in Landscape), by Star Gossage, 2005.

Oil on paper, 3 Io mm x 390 mm. Photograph by Kallan MacLeod.

Private collection. Reproduced courtesy of the artist and

Tim Melville Gallery, Auckland.

Lovers embrace earth tones upon textured ground . . a thicket of trees

MOANA NEPIA 